\title{
The effect of unregistered assets and information trans- parency on the firm's performance and stock liquidity in the listed firms in Tehran Stock Exchange
}

\author{
Farideh Asadi $^{1}$, Majid Moradi ${ }^{2}$, Davoud Ghorjizadeh ${ }^{3}$ \\ 1, 2, 3 Naser Khosro Institute of Higher Education of Saveh, Saveh, Iran
}

\section{Keywords \\ Unregistered assets Information transparency Firm's performance \\ Stock liquidity}

Received: 8 September 2020 Accepted: 3 December 2020 Published: 15 February 2021

\begin{abstract}
Liquidity is one of the important variables in investors' decisions to evaluate risk and return on securities. High liquidity in a stock exchange is the success of that market in clarifying and approaching the price of securities to their intrinsic value. Stock with high liquidity naturally carries less risk. Because it has a high speed of changing to liquidity. Therefore, investors try to select a stock with high liquidity to escape risk. The objective of this research is to investigate the effect of unregistered assets and information transparency on a firm's performance and stock liquidity in the listed firms in the Tehran Stock Exchange. This research was conducted in the period 2011-2018. The objective of this research is applied and the methodology is content correlation based on its type. The research was conducted within the framework of deductive-inductive reasoning. In addition, panel analysis was used to analyze hypotheses. The results of testing hypotheses showed that the unregistered assets Research and Development (R\&D) costs index, firm's development, and capital costs index) had a positive and significant effect on the stock liquidity. However, they did not have a significant effect on the firm's performance. Moreover, the results showed that information transparency did not have a significant effect on the firm's performance but has a positive and significant effect on the stock liquidity.
\end{abstract}

(c) 2021 The Author(s). Published by TAF Publishing.

\section{INTRODUCTION}

Liquidity is a key measure of the quality of the capital market and is a prerequisite for market growth and development. Liquidity is directly related to the expected return of investment by investors and is a major effective criterion on the efficiency of asset pricing (Albao, 2018; Foroughnejad \& Moradi, 2014). Managers, who did not consider the stock liquidity and finance by high capital price, face nonused assets, failed investments, and overdue debt installments, that do not have cash to meet them. Therefore, their ability will reduce in administrating the affairs (Edmans \& Manso, 2011). Therefore, managers will be reduced their obligations at a higher rate and will be deprived of suitable investment opportunities by losing their ability to manage the company's affairs. There are models based on agency and information issues in stock prices that state the rela- tionship between stock liquidity and investment. Liquidity facilitates the entry of major shareholders into the stock market (Palmiter, 2001).

Collins, Kothari, Shanken, and Sloan (1994) found that the lack of timely and random and noisy interpretations (bugs) led to unfavorable reporting of current earnings. One of the effective factors on the lack of timely accounting information is the identification of intangible assets. Estimation less than the actual amount of intangible assets is mainly because of the related issues to R\&D costs and estimation less than the actual amount of future profits from new assets. $R \& D$ costs are identified as the cost of the period in which they occurred. If R\&D is successful, the firm will have significant development opportunities which show that the firm does not own any intangible assets. However, if $R \& D$ is unsuccessful, the firm is equal to firms with no intangible as-

* corresponding author: Majid Moradi

†email:m.moradi@hnkh.ac.ir 
sets (Chan, Hong, \& Subrahmanyam, 2008). This marking theory states that management is interested in providing more information when firms have good news or are rated less than actual. Thus, the higher the R\&D costs, the fewer intangible assets are registered (Chen, Rhee, Veeraraghavan, \& Zolotoy, 2015).

\section{Problem Statement}

Successful guidance of a firm without the relevant performance data to the strategic decision evaluation is impossible. In this regard, the extensive acceptance of information technology has led to assets as the main determinant of firm value to impair performance information (Foroughnejad \& Moradi, 2014). Since the main objective of financial reporting is providing useful information to the users to make a decision and evaluate how to allocate the limited resources, non-registering the assets reduces the usefulness of financial statements (Dahmash, Durand, \& Watson, 2009). Accounting commentators believe that the removal of assets from the balance sheet makes a major challenge to financial reporting and explains how accountants can report balance sheets to ignore important assets such as trademarks, supply chain, knowledge, human capital, organizational capital, especially when the value of today's corporations is derived from such assets rather than tangible assets (Penman, 2009). On the other hand, capital market participants are always looking for quality financial information because this information reduces information asymmetry between the firm's management and external investors. The empirical evidence shows that a broad and transparent disclosure policy is a mechanism that reduces information asymmetry between managers and external investors. Transparency and disclosure of corporate information can be considered as a mechanism, to support investors, which in turn lead to less information asymmetry and reduced agency costs. Information asymmetry will have different adverse consequences such as increased transaction costs, weak market, low liquidity, and generally reduced profits from transactions in the capital market (Chen et al., 2015).

Liquidity is one of the most important variables in investors' decisions regarding risk assessment and returns on securities. High liquidity in a stock exchange indicates its success in making information transparent and the proximity of securities prices to their intrinsic value. Highly liquid stocks naturally have less maintaining risk because they have a high rate of cash conversion. Therefore, investors try to choose a high liquidity stock because of the nature of risk aversion (Chen et al., 2015; Ray, 2019). Furthermore, one of the most important objectives of economic enterprises is to gain profit and increase the wealth of shareholders (owners) in the long run. Shareholders, creditors, and other groups associated with businesses need reliable and relevant information about their performance and managers to make logical decisions. As the shareholders and creditors allocate their limited financial resources to businesses, performance appraisal is the formal process of providing information about the results of work. This matter identifies the strengths of the organization and magnifies it to create more values and in fact more desirable performance because it looks to the future to help set the values by analyzing the past activities of the firm (Alatrash, 2018; Penman, 2009).

According to what was mentioned, this research tries to answer this question, whether the unregistered assets and information transparency have a positive and significant effect on the firm's performance and stock liquidity in the listed firms in Tehran Stock Exchange or not?

\section{Research Necessity and Importance}

The ability to achieve the desired and expected level of performance is in a state of ambiguity in today's turbulent world where organizations and societies are facing dramatic environmental and technological changes and, consequently, global trade and globalization. In this way, what can ensure the growing and developmental life of organizations is the existence of a powerful and efficient management system. In other words, the good performance of organizations in the current situation can be expected only in the case of the authority and capability of the management pillar of the organization. The subtle and definite point is that the manager cannot penetrate in her/his colleagues and subordinates unless he/she is capable and efficient. In other words, lack of necessary skills in doing things, causes employees to try to resolve and refer to things by creating informal relationships, people get out of their main tasks, and hit the whole system with inappropriate decisions (Nezam, Ataffar, Isfahani, \& Shahin, 2016). According to the mentioned issues and the importance of unregistered assets and information transparency on a firm's performance and stock liquidity for investors, the impact of unregistered assets and information transparency will be studied on a firm's performance and stock liquidity in this research. Furthermore, many empirical studies confirmed the fact that transparency of information through the channel of liquidity and reduction of capital costs can influence the value of the firm. Therefore, according to the above and the growing importance of discussing firm performance and stock liquidity in this study, the effect of unregistered assets and information 
transparency on firm performance and stock liquidity will also be examined.

\section{Research Objectives}

The main objective of this research is to study the effect of unregistered assets and information transparency on the firm's performance and stock liquidity in the listed firms in the Tehran Stock Exchange.

The main question of research

First question: Do unregistered assets have a positive and significant effect on the firm's performance? 1-1 Do unregistered assets (firm R\&D cost index) have a positive and significant effect on a firm's performance?

1-2 Do unregistered assets (capital cost index) have a positive and significant effect on the firm's performance?

Second question: Do unregistered assets (R\&D cost index) have a positive and significant effect on stock liquidity?

1-1 Do unregistered assets (R\&D cost index) have a positive and significant effect on stock liquidity?

1-2 Do unregistered assets (capital cost index) have a positive and significant effect on stock liquidity?

Third question: Does information transparency have a positive and significant effect on firm performance?

Fourth question: Does information transparency have a positive and significant effect on the firm's stocks liquidity?

\section{LITERATURE REVIEW}

Collins et al. (1994) investigated the relationship between the management rank based on the value and financial performance of the firm. The results of the research showed a strong relationship between the criteria for measuring the performance of value-based management and the financial performance of firms. In this regard, there are 3 classifications based on the reduction of cash flow, added value, and capital cost 3 criteria. The criteria based on the added value have the maxim relationship with the firms' performance. Dahmash et al. (2009) investigated the capital market liquidity in the critical financial condition. The research results showed the negative and significant relationship between financial limitations and stock market liquidity. Moreover, there is no significant relationship between the financial crisis and liquidity.

Glosten and Milgrom (1985) investigated the effect of information quality on the stock liquidity risk and market risk. The research results showed a significant relationship between three criteria of information quality with the stock liquidity risk. In this regard, the higher accruals quality and timely announcement of earnings reduce stock liquidity risk, and higher percentages of earnings forecast errors in- crease stock liquidity risk. However, no significant relationship was found between the criteria of information quality and market risk.

Hu, Zhong, and Cai (2019) investigated information transparency and stock liquidity. The results of their research showed a positive and significant relationship between information transparency and stock liquidity. In addition, the results indicated no significant relationship between the criterion of transparency and the expected return of shareholders. Penman (2009) investigated the relationship between investors' emotional tendencies and stock liquidity. The results showed that investors' tendencies increase stock market liquidity.

Krestina (2018) investigated the relationship between risk management and firm performance whose results showed a positive relationship between risk management and the firm's performance.

Chen et al. (2015) investigated the relationship between unregistered assets, information disclosure, profit response coefficient, and comparison of disclosure effects on the relationship between profit and return (as indicators to evaluate the firm's performance) as well as the Amihud model to evaluate the stock liquidity for firms with various levels of unregistered assets. The results showed the positive and significant relationships between unregistered assets and information transparency. Firms with more unregistered assets have higher futures response rates. In addition, they concluded that higher amounts of unregistered assets have a higher effect on earnings response and future earnings response by comparing firms with different amounts of unregistered assets. Moreover, they concluded that firms with R\&D costs or high capital costs can increase their information transparency to remove information asymmetry and increase their firm's stock liquidity by this way.

Mangena and Tauringana (2007) found a positive and significant relationship between transparency, foreign ownership, and quiddity in South African firms. Their findings are in agreement with the logic that foreign investors tend to invest in firms that have corporate governance and effective transparency, which increases the level of value of the firm. Ogbonna and Wilkinson (2003) investigated the false managerial self-confidence and financial performance of large companies whose results showed a positive and significant relationship between false managerial self-confidence and the financial performance of companies. Glosten and Milgrom (1985) in their research on American companies concluded that the differences in stock buying and selling prices decrease and so stock liquidity increases by increasing transparency of information about companies. In addi- 
tion, the findings of their research showed that increasing transparency reduces the phenomenon of incorrect selection. Chen et al. (2015) investigated the effect of stock liquidity on short-term management attitudes. They considered earnings management as a factor to identify the shortterm attitude of managers. The results of their research showed that stock liquidity will reduce earnings management. As noticed, the main objective of this research is to study the effect of unregistered assets and information transparency on the performance of the company and stock liquidity in the listed companies in the Tehran Stock Exchange.

\section{Research Hypotheses}

H1: Unregistered assets have a positive and significant effect on the firm's performance.
1. Unregistered assets ( $R \& D$ cost index) have a positive and significant effect on firm performance.

2. Unregistered assets (capital cost index) have a positive and significant effect on the firm's performance.

H2: Unregistered assets ( $\&$ D cost index) have a positive and significant effect on stock liquidity.

1. Unregistered assets ( $R \& D$ cost index) have a positive and significant effect on stock liquidity.

2. Unregistered assets (capital cost index) have a positive and significant effect on stock liquidity.

H3: Information transparency has a positive and significant effect on the firm's performance.

H4: Information transparency has a positive and significant effect on the firm's stock liquidity.

The Detailed Conceptual Research Model

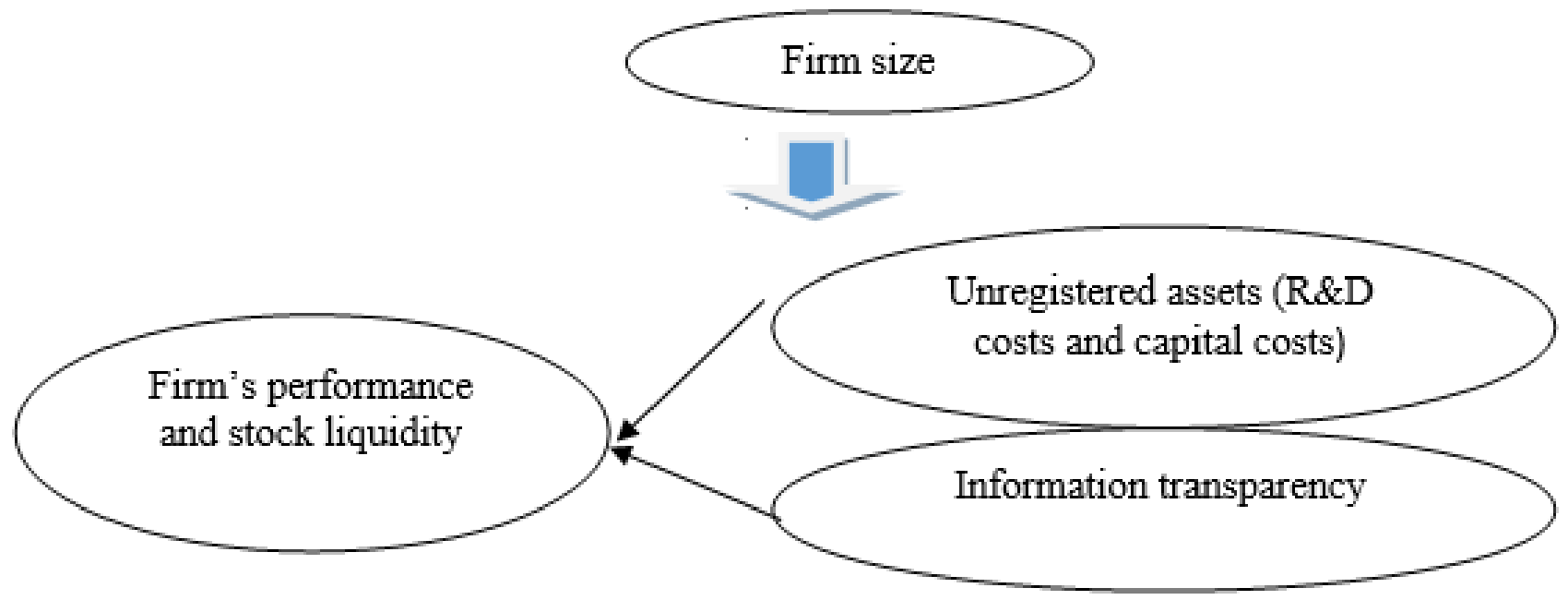

FIGURE 1. Conceptual model (Chen et al., 2015)

As it is seen in Figure 1, this research tries to answer two questions: first, do unregistered assets (R\&D costs and capital costs) and information transparency influence the firm's performance, stock liquidity, and firm size?

According to the contents mentioned in the research variables, the dependent variables include the firm's performance and stock liquidity. In addition, the independent variables include unregistered assets (R\&D costs and capital costs) and information transparency. The control variable includes the firm size.

\section{Research Statistical Model}

In this research, the following statistical model is used to analyze the hypothesis, as Alavi, Nemati Koshteli, and Haghighat (2014) research:
Model $1-1$ and $1-2$ of research:

FPi. $t=\alpha 0+\alpha 1 R \& D I N D+\alpha 2$ CAPIND $+\alpha 3 S I Z E+\varepsilon i, t$ Model $1-2$ and $2-2$ of research:

$L_{i, t}=\alpha_{0}+\alpha_{1} R \& D I N D+\alpha_{2} C A P I N D+\alpha_{3} S I Z E+\varepsilon_{i, t}$

Research third model:

$\mathrm{FP}_{i, t}=\alpha_{0}+\alpha_{1}$ TRANSP $+\alpha_{2}$ SIZE $+\varepsilon_{\mathrm{i}, \mathrm{t}}$

Research fourth model:

$L_{i, t}=\alpha_{0}+\alpha_{1}$ TRANSP $+\alpha_{2} S I Z E+\varepsilon_{i, t}$

The components of the mentioned model include:

FP: Firm performance in firm $i$ in year t; R \& DIND: R\&D costs index of firm $i$ in year $t$; CAPIND: Index of capital costs in the firm $\mathrm{i}$ in year $t$;

L: stock liquidity of firm $i$ in year $t$

TRANSP: information transparency in firm $i$ in year $t$; Size: 
size of firm $i$ in year $t$; sit: regression equation error; $\alpha$ : The relational value of variables; Research variables Dependent variable: firm's performance The assets are calculated using the return ratio: $2-1-7-3-1$ stock liquidity BAS $=\frac{1}{D} \sum_{D=1}^{D i . t} \frac{\text { Aski. } d-\text { Bid }}{\text { Aski.d } d+\frac{\text { Bidid. }}{2}}+\cdots$

BAS: the difference between the bid prices of the stock; Askid: the best (minimum) suggested selling price of daily stock for firm $i$;

Bidi.d: the best (maximum) suggested selling price for daily stock of firm $i$;

$\frac{1}{B A S i . t}$ Will be used in this model to measure the stock liquidity.

\section{METHODOLOGY}

\section{Independent Variable: Unregistered Assets}

It is calculated using R\&D costs index of firm (if the firm has $\mathrm{R} \& \mathrm{D}$ costs, it is 1 ; otherwise, it is 0 ) and the capital costs index (purchase of long-term assets) (if the firm has capital costs, it is 1 ; otherwise, it is 0 ).

\section{Information transparency}

Information transparency index is an information that is announced every year by the Tehran Stock Exchange and consists of two indexes of timeliness and reliability.

\section{Control variables: Firm size}

The book value of the firm's total assets at the end of the year is calculated by natural logarithm.

Conditions to select the research statistical sample volume include: 1- The firm was listed on the stock exchange before 2011 and is active in the stock exchange until the end of 2017;

2- The selected firm should not be one of the mentioned firms because of the special nature of the activities of holding firms, insurance, leasing, banks, financial and investment institutions and their significant differences with manufacturing and trading firms;

3- The financial year of the firm should end on March 20 and there should be no change in the financial year during the research period;

4- The firm should not have a trading interruption for more than 3 months during the financial year of this research period;

5- The needed information is available in the variables definition section.

Number of firms is in Table 1 for $(120 * 8=960)$ year-firm as a sample volume by considering these variables finally among all the listed firms in Tehran Stock Exchange.

TABLE 1. Determining the research statistical sample volume

\begin{tabular}{lc}
\hline \hline Description & No. \\
\hline Number of the listed firms in Tehran Stock Exchange at the end of 2018 & 520 \\
Number of firms that were not active in the stock market in the period of 2011-2018 & 171 \\
A number of the listed firms in Tehran stock exchange since 2011 & 51 \\
Number of firms other than holding, investments, financial intermediation, banks or leasing & 55 \\
Number of firms that have changed the financial year in the research area or their fiscal year does not & 52 \\
end in March & 55 \\
Number of firms in the research area that have had a trading break of more than 3 months & - \\
Inaccessibility to information & 135 \\
Number of firms whose information is not accessible in the scope of the research \\
Number of sample firms
\end{tabular}

135 firms remained as a screened community, all of which were selected as a research sample after considering all the mentioned criteria. Therefore, 960 firms (8 years*135 firms) were considered based on observations in 2011-2018.

\section{Research Area}

The subject area of this research based on its theory is related to the field of accounting financial management research, which seeks to examine the impact of unregistered assets and information transparency on the firm's perfor- mance.

The spatial territory is sufficiently reliable according to the financial statements as well as other financial information of the listed firms in the Iranian capital market. Therefore, the spatial area of the listed firms in the Tehran Stock Exchange in this research was selected.

The time area is transparently and explicitly mentioned for researching a specific time range and the importance of time in data collection as well as presenting research findings in the research design. 8 year period, 2-11-2018 can be known as the proper time for research. 
TABLE 2. Descriptive statistics of research quantitative variables

\begin{tabular}{|c|c|c|c|c|c|c|c|c|c|}
\hline \multicolumn{3}{|c|}{ Name and no of Variables } & \multicolumn{2}{|c|}{ Central indexes } & \multicolumn{5}{|c|}{ Kurtosis indexes } \\
\hline Variable & Abbreviation & No & Mean & Median & St.Dev & Skewness & Kurtosis & Min & Max \\
\hline R\&D costs & R\&DIND & 1080 & 0.32 & 0 & 0.43 & 0.54 & 2.35 & 0 & 1 \\
\hline Capital costs & CAPIND & 1080 & 0.98 & 1 & 0.11 & -0.76 & 1.45 & 0 & 1 \\
\hline Stock liquidity & LIQ & 1080 & 0.772 & 0.834 & 0.22 & -1.43 & 3.65 & 0.32 & 0.98 \\
\hline Transparency & TRANSP & 1080 & 3.65 & 4 & 0.61 & -1.54 & 3.76 & 0 & 4 \\
\hline FP & FP & 1080 & 0.18 & 0.16 & 0.15 & 0.74 & 3.54 & -0.046 & 0.78 \\
\hline Size & Size & 1080 & 13.92 & 13.69 & 1.54 & 0.98 & 4.03 & 11.23 & 19.45 \\
\hline
\end{tabular}

\section{RESULTS}

\section{Descriptive Analysis of Rsearch Variables}

Among the research variables, capital costs, liquidity, and information transparency have a negative skewness whose median is high than its mean. Considering the positive skewness coefficient of others, it can be said that the distribution of the mentioned variables has skewness to the right side. The means lower than the average R\&D costs $(0.3)$ show that fewer sample firms reported $R \& D$ costs, but the means higher than the capital costs $(0.98)$ show the high capital costs in the sample firms. The mean stock liquidity of the studied firms shows that the number of open trading days of each symbol was the total number of trading days in each year (0.772). This indicates that the firms' symbols are banned for one-fifth of the year. In other words, 77\% of the days that the Tehran Stock Exchange is open for trading were average the firms' stocks for the active transaction. The high level of information transparency (3.65) of the studied firms shows the relatively high level of transparency of firms' reporting based on the criteria of the Exchange Organization (reliability and timeliness). The annual return of firms which is a measure of firm performance, having an average return of 0.18 and maximum of 0.78 , indicates its changes compared to previous years because of the stock market boom in 2018.

\section{Regression Estimation}

The regression estimation is conducted according to the obtained results in this part and heterogeneity of variance, autocorrelation, and collinearity. All the regressive preassumptions are correct because there was no heterogeneity of variance, autocorrelation, and collinearity in the research models. Therefore, the research hypotheses are studied.

$\mathrm{H} 1$ the unregistered assets have a positive and significant effect on the firm's performance.

1-1- unregistered assets (R\&D cost index) have a positive and significant effect on a firm's performance.

1-2- unregistered assets (capital cost index) have a positive and significant effect on the firm's performance. The following statistical model was used in this research for analysis to study the hypothesis such as (Atafar \& Azarbayejani, 2001) research.

FPi.t $=\alpha 0+\alpha 1 R \& D I N D+\alpha 2$ CAPIND $+\alpha 3 S I Z E+\varepsilon i, t$

According to Table 3, the significance of the model depends on F-value and $p$-value which are calculated for each regression model. If the $p$-value for this statistic is less than 0.05 "no significant relationship" is rejected and there is a significant relationship at the $95 \%$ confidence level, which is less than 0.05 in Table 3. It can be claimed that the significance of the model is confirmed. In addition, the model determination coefficient shows that $43.67 \%$ of the changes in the firm's performance are explained by the inserted variables in the model. Furthermore, since the Durbin-Watson value is 1.5-2.5 (1.98), the independence of the model residues is confirmed.

According to the obtained results from Table 3, sig. level ( $p$-value) for the $t$-value of R\&D costs variables was higher than 0.05 (0.098). It means it is insignificant, its coefficient is positive (7.78), and its $t$-value is 1.27. Furthermore, sig. level ( $p$-value) for $t$-value of capital costs variable was higher than 0.05 (0.117), which means it is insignificant, its coefficient is positive (4.99), and its $t$-value is 1.69 which is not in the area of rejecting. Therefore, it can be stated that unregistered assets are insignificant in the research model. It means the unregistered assets do not have a positive and significant effect on the firm's performance. Thus, the $\mathrm{H} 1$ is rejected.

$\mathrm{H} 2$ the unregistered assets have a positive and significant effect on the stock liquidity.

1-1 The unregistered assets (R\&D costs variable) have a positive and significant effect on the stock liquidity.

1-2 The unregistered assets (capital costs variable) have a positive and significant effect on the stock liquidity. 
TABLE 3. Dependent variable: Firm's performance

\begin{tabular}{|c|c|c|c|c|}
\hline Variable & Coefficients & $t$-Value & $p$-Value & Results \\
\hline R\&DIND & 7.78 & 1.27 & 0.098 & Insignificant \\
\hline CAPIND & 4.99 & 1.69 & 0.117 & Insignificant \\
\hline SIZE & 3.65 & 2.18 & 0.036 & Significant \& positive \\
\hline $\mathrm{C}$ (constant value) & -0.73 & -4.09 & 0.000 & Significant \& negative \\
\hline Durbin-Watson & & DW-stat & 1.98 & $\begin{array}{l}\text { The default of error indepen- } \\
\text { dence is accepted because } \\
\text { Durbin-Watson statistic is be- } \\
\text { tween } 1.5 \text { to } 2.5\end{array}$ \\
\hline $\begin{array}{l}\text { Adjusted coefficient } \\
\text { of determination }\end{array}$ & & $R^{2}$ & 0.4367 & $\begin{array}{l}43 \% \text { of the dependent variable } \\
\text { changes are expressed by ex- } \\
\text { planatory variables (independent } \\
\text { and control). }\end{array}$ \\
\hline Fisher statistics & & $F$-stat & 41.65 & \\
\hline Sig level of model & & $p$-Value & 0.000 & $\begin{array}{l}\text { The default of model being sig- } \\
\text { nificant is confirmed. It means } \\
\text { the model is linear because the } \\
\text { sig. level of Fisher statistics is less } \\
\text { than } 5 \% \text {. }\end{array}$ \\
\hline
\end{tabular}

TABLE 4. Dependent variable: Stock liquidity

\begin{tabular}{|c|c|c|c|c|}
\hline Variable & Coefficients & $t$-Value & $p$-Value & Results \\
\hline R\&DIND & 12.80 & 3.87 & 0.034 & Significant \& positive \\
\hline CAPIND & 8.94 & 2.70 & 0.040 & Significant \& positive \\
\hline SIZE & 3.98 & 2.69 & 0.028 & Significant \& positive \\
\hline $\mathrm{C}$ (constant value) & -0.54 & -3.87 & 0.000 & Significant \& negative \\
\hline Durbin-Watson & & DW-stat & 1.93 & $\begin{array}{l}\text { The default of error indepen- } \\
\text { dence is accepted because } \\
\text { Durbin-Watson statistic is be- } \\
\text { tween } 1.5 \text { to } 2.5\end{array}$ \\
\hline $\begin{array}{l}\text { Adjusted coefficient } \\
\text { of determination }\end{array}$ & & $R^{2}$ & 0.3970 & $\begin{array}{l}39 \% \text { of the dependent variable } \\
\text { changes are expressed by ex- } \\
\text { planatory variables (independent } \\
\text { and control). }\end{array}$ \\
\hline Fisher statistics & & $F$-stat & 32.60 & \\
\hline Sig level of model & & $p$-value & 0.000 & $\begin{array}{l}\text { The default of model being sig- } \\
\text { nificant is confirmed. It means } \\
\text { the model is linear because the } \\
\text { sig. level of Fisher statistics is less } \\
\text { than } 5 \% \text {. }\end{array}$ \\
\hline
\end{tabular}

According to Table 4, the significance of the model depends on $F$-value and $p$-value which are calculated for each regression model. If the $p$-value for this statistic is less than 0.05 , "no significant relationship" is rejected and there is a significant relationship at the $95 \%$ confidence level, which is less than 0.05 in Table 4, so the significance of the model is confirmed. In addition, the model determination coefficient shows that $39.70 \%$ of the changes in the stock liquidity are explained by the inserted variables in the model. Furthermore, since the Durbin-Watson value is 1.5-2.5 (1.93), the 
independence of the model residues is confirmed. According to the obtained results from Table 4, sig. level ( $p$-value) for the $t$-value of $R \& D$ costs variables was higher than 0.05 (0.034). It means it is insignificant, its coefficient is positive (12.80), and its $t$-value is 3.87. Furthermore, sig. level ( $p$-value) for $t$-value of capital costs variable was lower than $0.05(0.040)$, which means it is significant, its coeffi- cient is positive (8.94), and its $t$-value is 2.70 which is in area of rejecting. Therefore, it can be stated that unregistered assets are significant and positive in the research model. It means the unregistered assets have a positive and significant effect on liquidity. Thus, the $\mathrm{H} 2$ is confirmed.

H3 the information transparency has a positive and significant effect on the stock liquidity.

TABLE 5. Dependent variable: Firm's performance

\begin{tabular}{|c|c|c|c|c|}
\hline Variable & Coefficients & $t$-Value & $p$-Value & Results \\
\hline TRANSP & 0.005 & 0.71 & 0.134 & Insignificant \\
\hline SIZE & 0.0004 & 0.89 & 0.276 & Insignificant \\
\hline $\mathrm{C}$ (constant value) & 0.353 & 4.67 & 0.005 & Significant \& positive \\
\hline Durbin-Watson & & DW-stat & 1.78 & $\begin{array}{l}\text { The default of error indepen- } \\
\text { dence is accepted because } \\
\text { Durbin-Watson statistic is be- } \\
\text { tween } 1.5 \text { to } 2.5\end{array}$ \\
\hline $\begin{array}{l}\text { Adjusted coefficient } \\
\text { of determination }\end{array}$ & & $R^{2}$ & 0.3970 & $\begin{array}{l}51 \% \text { of the dependent variable } \\
\text { changes are expressed by ex- } \\
\text { planatory variables (independent } \\
\text { and control). }\end{array}$ \\
\hline Fisher statistics & & $F$-stat & 17.98 & \\
\hline Sig level of model & & $p$-value & 0.000 & $\begin{array}{l}\text { The default of model being sig- } \\
\text { nificant is confirmed. It means } \\
\text { the model is linear because the } \\
\text { sig. level of Fisher statistics is less } \\
\text { than } 5 \% \text {. }\end{array}$ \\
\hline
\end{tabular}

According to Table 5, the significance of the model depends on $F$-value and $p$-value which are calculated for each regression model. If the P-value for this statistic is less than 0.05 , "no significant relationship" is rejected and there is a significant relationship at the $95 \%$ confidence level, which is less than 0.05 in Table 5 , so the significance of the model is confirmed. In addition, the model determination coefficient shows that $51.07 \%$ of the changes in the firm's performance are explained by the inserted variables in the model. Furthermore, since the Durbin-Watson value is 1.5-2.5 (1.78), the independence of the model residues is confirmed.

According to the obtained results from Table 5, sig. level ( $p$-value) for $t$-value of information transparency variable was less than $0.05(0.134)$. It means it is insignificant, its coefficient is positive (0.005), and its $t$-value is 0.71 . Its $t$-value is 0.71 which is not in the area of rejecting. Therefore, it can be stated that information transparency in the research model is insignificant. It means that information transparency does not have a positive and significant effect on the firm's performance. Thus, the H3 is rejected.

H4 the information transparency has a positive and signif- icant effect on the stock liquidity. According to Table (6), the significance of the model depends on F-value and pvalue which are calculated for each regression model. If the P-value for this statistic is less than 0.05, H0 "no significant relationship" is rejected and there is a significant relationship at the $95 \%$ confidence level, which is less than 0.05 in Table 6 , so the significance of the model is confirmed. In addition, the model determination coefficient shows that $62.04 \%$ of the changes in the stock liquidity are explained by the inserted variables in the model. Furthermore, since the Durbin-Watson value is 1.5-2.5 (1.84), the independence of the model residues is confirmed. According to the obtained results from Table 6, sig. level ( $p$-value) for $t$-value of information transparency variable was less than 0.05 (0.037). It means it is insignificant, its coefficient is positive (0.42), and its $t$-value is 2.45 which is in the area of rejecting. Therefore, it can be stated that information transparency is significant and negative in the research model. It means that information transparency has a positive and significant effect on stock liquidity. Thus, the H4 is confirmed. 
TABLE 6. Dependent variable: Stock liquidity

\begin{tabular}{|c|c|c|c|c|}
\hline Variable & Coefficients & $t$-Value & $p$-Value & Results \\
\hline TRANSP & 0.42 & 2.45 & 0.037 & Significant \& positive \\
\hline SIZE & 0.002 & 0.39 & 0.342 & Insignificant \\
\hline C (constant value) & 6.58 & 9.47 & 0.000 & Significant \& positive \\
\hline Durbin-Watson & & DW-stat & 1.84 & $\begin{array}{l}\text { The default of error indepen- } \\
\text { dence is accepted because } \\
\text { Durbin-Watson statistic is be- } \\
\text { tween } 1.5 \text { to } 2.5\end{array}$ \\
\hline $\begin{array}{l}\text { Adjusted coefficient } \\
\text { of determination }\end{array}$ & & $R^{2}$ & 0.6204 & $\begin{array}{l}62 \% \text { of the dependent variable } \\
\text { changes are expressed by ex- } \\
\text { planatory variables (independent } \\
\text { and control). }\end{array}$ \\
\hline Fisher statistics & & $F$-stat & 11.40 & \\
\hline Sig level of model & & $p$-value & 0.000 & $\begin{array}{l}\text { The default of model being sig- } \\
\text { nificant is confirmed. It means } \\
\text { the model is linear because the } \\
\text { sig. level of Fisher statistics is less } \\
\text { than } 5 \% \text {. }\end{array}$ \\
\hline
\end{tabular}

\section{DISCUSSION \& CONCLUSION}

The unregistered assets of some items of intangible assets are the ones not considered in the balance sheet but are a source of making value. According to the accepted accounting principles, R\&D costs, as current costs, reduce the current profits. Two main products of R\&D activity are science and technology and establishing a systematic relationship between them. Establishing such relationships in a short time is a key factor for the growth and development of firms. Despite the other intangible investments, investment in the R\&D sector shows the relationship between the value creation of the firm and R\&D costs clearly. The internal and external users of financial statements analyze the inforSmation of R\&D costs economic consequences. The usefulness of this information is confirmed based on the impact of the consequences on the value of the firm. Because experience has shown that R\&D costs are significantly related to the firm's future performance. Future cash flows expected to be generated by $R \& D$ costs are reflected in current profits. Lack of timely disclosure of accounting information creates a weak relationship between current returns and current profits. a well-informed capital market can significantly determine the nature of the effects while facing an economic disaster. Logical investors in the capital market tend to reconcile expected and realized future profits that change the firm's stock prices and return on investment. This matter shows the necessity of investigating the relationship between the unregistered assets such as R\&D costs, capital costs with liquidity, the firm's performance, and the effect of information transparency on liquidity and performance. The result of the $\mathrm{H} 1$ showed that unregistered assets have no significant effect on a firm's performance. This result is contrary to the research of (Dehghanyar \& Mohammadzadeh, 2018). Ginesti, Caldarelli, and Zampella (2018) showed in their research under the title of "the effect of unregistered assets and information disclosure on firm's performance and stock liquidity (liquidity ratio) that firms with high levels of unregistered assets have a high return on assets. However, this result is relatively in agreement with the findings of Florio and Leoni (2017), and Srinivasan, Pauwels, Silva-Risso, and Hanssens (2009). Baily (1972) showed that there is no significant relationship between research and development costs and stock returns in their research. In addition, Srinivasan et al. (2009) concluded in their research that there is no significant relationship between intangible assets with return on investment, earnings per share, and cash earnings per share. The results of this research and other similar domestic research are different from the result of Chen et al. (2015) research because the condition of the capital market in Iran and the effective factors on it is different from the condition of the foreign capital market. This research may be obtained because of the emerging capital market in Iran, lack of awareness of investors about research, development costs, more effective rumors, etc.

The results of the second hypothesis of the research showed that $R \& D$ costs and higher capital costs provide more information transparency. Therefore, firms with higher unreg- 
istered assets provide more transparent information by reducing information asymmetry which finally increases the firm's stock liquidity. Actually, it can be inferred by this positive effect on unregistered assets on the performance and liquidity that e.g. increasing costs of innovation in the firm (which is a key index for success and growth of firm) will increase the firm's competitive power which is caused by R\&D costs. In this case, managers tend to disclose more information to avoid underestimating stock prices, and high transparency of information leads to investor confidence about the future of the firm's profits. Thus, R\&D costs and capital costs act as a positive signal for investors that can increase the firm's stock liquidity and return on assets. The results of this hypothesis are in line with the results of Chan et al. (2008) and Chen et al. (2015) studies. Chen et al. (2015) in their research, "The effect of unregistered assets and information disclosure on firm performance and stock liquidity (liquidity ratio)" showed that firms with high levels of unregistered assets have a liquidity ratio. Moreover, Chen et al. (2015) in another research studied the relationship between unregistered assets, information disclosure, profit response coefficient, comparison of the effects of disclosure on the relationship between profit and return (as indicators to evaluate the firm's performance). They concluded that firms with high R\&D costs or capital costs can increase their information transparency to address information asymmetry problems and to increase their firm's stock liquidity. The result of the third hypothesis showed that there is no significant relationship between information transparency and firm performance. This result is in agreement with the result of Chen et al. (2015) research. Chan et al. (2008) showed that firms with higher R\&D or higher capital costs can increase their information disclosure by reducing information asymmetry and increasing the firm's performance. However, this result is relatively in agreement with the findings of Hu et al. (2019), Nezam et al. (2016), and Mangena and Tauringana (2007). Hu et al. (2019) showed that there is no significant relationship between the criterion of transparency and the expected return of shareholders. Mousavi SHiri, Roshandel, and KHalatbari (2018) in their research under the title of "The role of information transparency in explaining the relationship between government political support and the performance of the listed firms in the Tehran Stock Exchange" concluded that there is no significant relationship between information transparency and return on assets. Nezam et al. (2016) also showed that there is no significant relationship between information transparency and firm value (Tobin's Q). There are much contradicted results about the effect of transparency on liq- uidity. Several studies have considered this effect as positive, some as negative, and some as ineffective.

The result of the fourth hypothesis showed that information transparency can increase liquidity. This result is in agreement with the findings of Chan et al. (2008), Florio and Leoni (2017), Hu et al. (2019), Mangena and Tauringana (2007), and in disagreement with the findings of Nezam et al. (2016). Chan et al. (2008), Florio and Leoni (2017), Hu et al. (2019) showed that there is a positive and significant relationship between information transparency and stock liquidity. In addition, Mangena and Tauringana (2007) found a positive and significant relationship between transparency and liquidity in South African firms. However, Nezam et al. (2016) showed a reverse relationship between transparency and liquidity. Furthermore, Krestina (2018) in relatively similar research showed that there is no significant relationship between the quality of disclosure and liquidity. The contradicted results in this research are probably because of different research periods and different criteria to evaluate transparency and liquidity. For example, the criteria of reliability, timeliness, reported profit, quality of accruals, etc., and to measure liquidity, the criteria of trading volume, Amihud criteria, bid-ask price, ratio of open trading days, etc. have been used in various studies. They have a positive effect on liquidity maybe because the investors react to the new information disclosure influencing their view about the firm's further performance. Actually, lack of transparency makes information risk. As a result, shareholders ask for higher risks, and consequently, the cost of capital of ordinary shares of the firm will increase. On contrary, the more transparent and unambiguous the profit, the more confident of the shareholders, especially the institutional shareholders, increase, the stock will be more attractive, and the stock liquidity will increase.

\section{Suggestions}

Here are some applied and research suggestions according to the obtained results from hypotheses for the further researchers:

The obtained results from the hypotheses of this research are in fact complementary to each other in the first, third, second, and fourth hypotheses. Actually, the effect of information transparency on performance and liquidity can better justify and interpret the effect of unregistered assets on performance and liquidity.

The applied suggestions from the results of this research 1 - According to the general findings of the research, it is suggested to decision-makers, analysts, and potential and actual investors of the Tehran Stock Exchange to consider 
unregistered assets and transparency of firm information, including the reliability and timeliness of firm information in their analytical research because it can contain useful information for decision making.

2- According to the results of the first and third hypotheses, it is suggested to the owners of the listed firms in Tehran Stock Exchange to make the investors aware of the status of unregistered assets, R\&D costs, and capital costs by informing and clarifying the relevant information to their financial statements. Because the results of this hypothesis showed that the status of registered assets and information provided about their status in the firm has not been able to sufficiently influence the return on assets and the result of investors' inclination to that firm despite foreign research. 3- According to the results of the second and fourth hypotheses, it is suggested to the owners of firms to increase the related costs to innovation and R\&D in the firm and reduce information asymmetry in this field to transmit appropriate signals to shareholders about their shares and make them aware of their stock liquidity.

4- It is suggested to the Securities Exchange Organization to require all the listed firms on the Tehran Stock Exchange to submit reports related to the registration and disclosure of R\&D costs, and capital costs, and intangible assets in financial statements to reduce information asymmetry.

5 - It is suggested to the auditing organization to consider the possibility of registering these assets because of the impact of unregistered assets on shareholders' decisions in stock buy-sell, and market value.

\section{Suggestions for the Further Studies}

1- It is suggested to study the effect of unregistered assets on other criteria such as liquidity ratios, stock returns, Tobin's $Q$, and other liquidity metrics such as bid-ask price and daily trading volume.

2- It is suggested to study the mediating role of industry types, firm's growth, sailing growth, etc. on the unregistered assets, performance, and liquidity.

\section{Limitations of the Study}

1- Generalization of the process of the past to the future is rational if the same conditions of the past are kept on. For example, the current political, economic, and legal conditions for companies should be the same as past.

2- Some of the listed companies in the Tehran Stock Exchange have not been active in the studied years, and trading in their stocks has been stagnant. Thus, data of these companies has not been used in this research.

3- Another of the most important limitations of this research is the historical nature of the items in the financial statements and the failure to adjust the effects of inflation on the research data. Therefore, the inflation effectiveness is probable on the relationships between variables. Inflation makes the information in the financial statements not show the financial condition and performance results of companies accurately.

\section{REFERENCES}

Alatrash, A. (2018). Impact of using total quality management on the financial performance of companies listed on the Palestine exchange. International Journal of Business and Economic Affairs, 3(6), 244-252. doi:https://doi.org/10 .24088/IJBEA-2018-36001

Alavi, M., Nemati Koshteli, R., \& Haghighat, H. (2014). Information transparency and stock liquidity. Empirical Research in Accounting, 4(2), 85-98. doi:https//doi.org/10.22051/JERA.2014.613

Albao, M. O. (2018). A comparative study of the retirement confidence level between domestic workers and OFW as linked to their job commitment. Journal of Administrative and Business Studies, 4(3), 136-144. doi:https://doi.org/10.20474/ jabs-4.3.2

Atafar, A., \& Azarbayejani, K. (2001). Investigating the degree of meritocracy in the selection of public and private managers. Journal of Management Knowledge, 54(5), 38-15.

Baily, M. N. (1972). Research and development costs and returns: The US pharmaceutical industry. Journal of Political Economy, 80(1), 70-85.

Chan, J. S., Hong, D., \& Subrahmanyam, M. G. (2008). A tale of two prices: Liquidity and asset prices in multiple markets. Journal of Banking \& Finance, 32(6), 947-960. doi:https://doi.org/10.1016/j.jbankfin.2007.07.002

Chen, Y., Rhee, S. G., Veeraraghavan, M., \& Zolotoy, L. (2015). Stock liquidity and managerial short-termism. Journal of Banking \& Finance, 60(6), 44-59. doi:https://doi.org/10.1016/j.jbankfin.2015.07.007

Collins, D. W., Kothari, S. P., Shanken, J., \& Sloan, R. G. (1994). Lack of timeliness and noise as explanations for the low contemporaneuos return-earnings association. Journal of Accounting and Economics, 18(3), 289-324. doi:https:// doi.org/10.1016/0165-4101(94)90024-8 
Dahmash, F. N., Durand, R. B., \& Watson, J. (2009). The value relevance and reliability of reported goodwill and identifiable intangible assets. The British Accounting Review, 41(2), 120-137. doi:https://doi.org/10.1016/j.bar.2009.03.002

Dehghanyar, S., \& Mohammadzadeh, A. (2018). Investigating capital market liquidity in the condition of financial crisis. Journal of Financial Management Strategy, 5(4), 83-102.

Edmans, A., \& Manso, G. (2011). Governance through trading and intervention: A theory of multiple blockholders. The Review of Financial Studies, 24(7), 2395-2428. doi:https://doi.org/10.1093/rfs/hhq145

Florio, C., \& Leoni, G. (2017). Enterprise risk management and firm performance: The Italian case. The British Accounting Review, 49(1), 56-74. doi:https://doi.org/10.1016/j.bar.2016.08.003

Foroughnejad, H., \& Moradi, J. M. (2014). Study of factors affecting the bid price gap of stock trading as a criterion for information asymmetry. Quarterly Journal of Investment Knowledge, 3(12), 24-33.

Ginesti, G., Caldarelli, A., \& Zampella, A. (2018). Exploring the impact of intellectual capital on company reputation and performance. Journal of Intellectual Capital, 11(5), 50-60. doi:https://doi.org/10.1108/JIC-01-2018-0012

Glosten, L. R., \& Milgrom, P. R. (1985). Bid, ask and transaction prices in a specialist market with heterogeneously informed traders. Journal of Financial Economics, 14(1), 71-100. doi:https://doi.org/10.1016/0304-405X(85)90044-3

Hu, S., Zhong, M., \& Cai, Y. (2019). Impact of investor behavior and stock market liquidity: Evidence from China. Entropy, 21(11), 11-25. doi:https://doi.org/10.3390/e21111111

Krestina, W. (2018). Exploration of phosphate solvent bacteria in gambut bereng bengkel land, central kalimantan. Jurnal Agri Peat, 19(2), 56-78.

Mangena, M., \& Tauringana, V. (2007). Disclosure, corporate governance and foreign share ownership on the Zimbabwe stock exchange. Journal of International Financial Management \& Accounting, 18(2), 53-85. doi:https://doi.org/10.1111/ j.1467-646X.2007.01008.x

Mousavi SHiri, M., Roshandel, M., \& KHalatbari, H. (2018). Investigation of the effect of information quality on stock liquidity risk and market risk. Journal of Asset Management and Financing, 6(2), 15-34. doi:https//doi.org/10.22108/AMF .2017.21171

Nezam, M. H. K., Ataffar, A., Isfahani, A. N., \& Shahin, A. (2016). Human capital and new product development performance efficiency-the mediating role of organisational learning capability. International Journal of Innovation and Learning, 20(1), 26-46. doi:https://doi.org/10.1504/IJIL.2016.076670

Ogbonna, E., \& Wilkinson, B. (2003). The false promise of organizational culture change: A case study of middle managers in grocery retailing. Journal of Management Studies, 40(5), 1151-1178. doi:https://doi.org/10.1111/1467-6486.00375

Palmiter, A. R. (2001). Mutual fund voting of portfolio shares: Why not disclose. Cardozo Law Review, 23, 14-19.

Penman, S. H. (2009). Accounting for intangible assets: There is also an income statement. Abacus, 45(3), 358-371. doi: https://doi.org/10.1111/j.1467-6281.2009.00293.x

Ray, P. K., A. \& Bala. (2019). Predicting user motivation towards retention of e-services: An NLP-based approach. International Journal of Business and Administrative Studies, 5(1), 1-8. doi:https://dx.doi.org/10.20469/ijbas.5.10001-1

Srinivasan, S., Pauwels, K., Silva-Risso, J., \& Hanssens, D. M. (2009). Product innovations, advertising, and stock returns. Journal of Marketing, 73(1), 24-43. doi:https://doi.org/10.1509/jmkg.73.1.024 